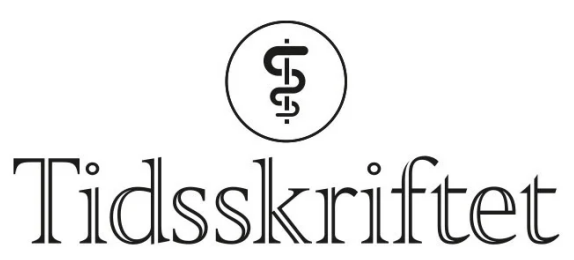

DEN NORSKE LEGEFORENING

\title{
Interessant om psykiatrisk diagnostikk
}

\author{
ANMELDELSER
}

\section{ANNE HØYE}

Allmenpsykiatrisk klinikk

Universitetssykehuset Nord-Norge

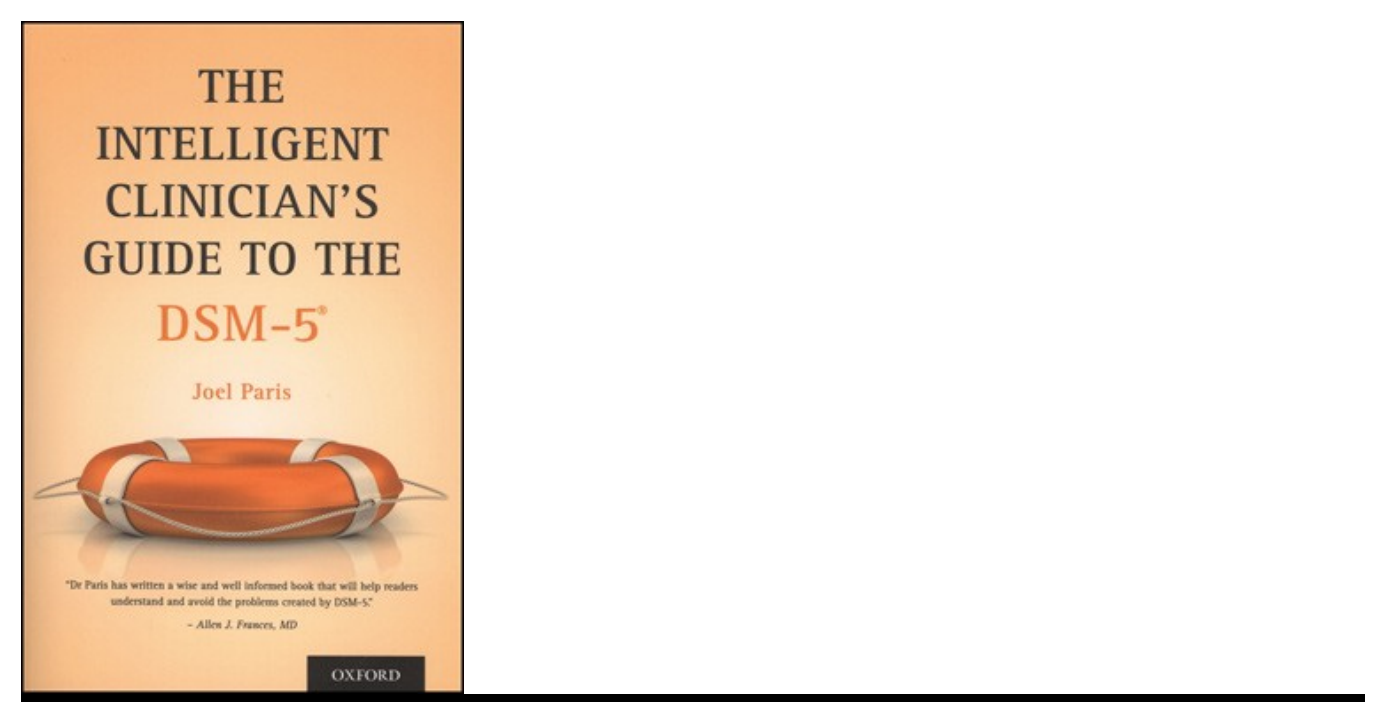

Paris, Joel

The intelligent clinician's guide to the DSM-5

232 s, ill. Oxford: Oxford University Press, 2013. Pris GBP 19

ISBN 978-0-19-973817-5

Utgivelsen av den amerikanske diagnosemanualen DSM-V i mai i år har ført til mye diskusjon, ikke bare i psykiatriske fagmiljøer. I denne boken gir Joel Paris en god innføring i problemene knyttet til psykiatrisk diagnostikk generelt, og DSM-V spesielt. Paris, professor i psykiatri i Montreal med mangeårig erfaring fra klinisk arbeid og forskning, er en nestor i faget. Han er også sjefredaktør for The Canadian Journal of Psychiatry. 
I Europa brukes ICD-10, men selv om søkelyset er rettet mot DSM-V, er teksten i høyeste grad interessant også for europeiske lesere. Diagnosekategoriene kan ha noe ulik utforming, men argumentasjonen er relevant for begge systemene.

Boken er inndelt i tre hoveddeler. I den første delen tar forfatteren for seg historiske fakta rundt psykiatrisk diagnostikk og definisjon av sykdom, validitet, reliabilitet og klinisk nytte. Han gir interessante innblikk i prosessen rundt utvikling av DSM-V og understreker at DSM-V ikke representerer noen egentlig forskjell fra DSM-IV. Det er bare tatt noen skritt videre når det gjelder å gjøre avgrensningen mellom normalitet og sykdom enda mer utydelig. Dette er Paris' viktigste poeng: Grensene utviskes, noe som fører til sykeliggjøring og overbehandling. Dette understrekes i den andre delen, der han beskriver diagnosegrupper nærmere. Den tredje og siste delen er en oppsummering.

Teksten fremstår som et velskrevet og velbegrunnet debattinnlegg. Forfatteren skriver underholdende og engasjert, selv om han gjentar hovedpoengene litt for ofte. Enkelte er sikkert uenige i argumentene når det gjelder for eksempel skepsis til tidlig diagnostikk av psykoser, inflasjon i bruk av diagnosen bipolar lidelse eller mangelfull og dårlig fundert avgrensning av depresjon, angst eller $\mathrm{AD} / \mathrm{HD}$, men argumentasjonen er overbevisende og basert på omfattende kunnskap fra ulike forskningsfelt. Forfatterens kritikk mot DSM-V (og ICD-10) er grunnleggende. På tross av dette mener han at en ufullstendig klassifisering er bedre enn ingenting. Hovedbudskapet er at både klinikere og forskere må vise stor grad av ydmykhet og pragmatisme når det gjelder diagnoser, stole på eget klinisk skjønn og være skeptiske til etablerte sannheter.

Boken er nok mest egnet for klinikere og forskere med over middels interesse for temaet, og mindre som håndbok for ferske klinikere. Likevel kan det være mye interessant og nyttig å hente, både i introduksjonskapitlet og i beskrivelsen av de ulike diagnosegruppene. De som ønsker en kort oppsummering, kan lese den siste delen, med den talende tittelen $A$ guide for the perplexed. Her gis et overblikk over hovedmomenter i en ikke spesielt enkel, men viktig debatt.

Publisert: 26. november 2013. Tidsskr Nor Legeforen. DOI: 10.4045/tidsskr.13.1216

(C) Tidsskrift for Den norske legeforening 2023. Lastet ned fra tidsskriftet.no 26. april 2023. 